\title{
Rokownicze znaczenie względnej intensywności dawki oraz wartości parametrów morfologii krwi w trakcie pooperacyjnej chemioterapii chorych na raka piersi
}

\author{
Ewa Szutowicz ${ }^{1}$, Barbara Radecka², Rafał Dziadziuszko ${ }^{1}$, Jacek Jassem¹
}

\begin{abstract}
Wstęp. Celem pracy była ocena rokowniczego znaczenia wybranych czynników klinicznych, w tym szczególnie intensywności dawki i hematologicznej toksyczności towarzyszącej pooperacyjnej chemioterapii u chorych na raka piersi. Materiał i metody. Przeanalizowano dane 264 chorych, które od stycznia 1990 do grudnia 1997 otrzymały 6 cykli pooperacyjnej chemioterapii według schematu CMF: cyklofosfamid $100 \mathrm{mg} / \mathrm{m}^{2}$ podawany doustnie od 1. do 14. dnia każdego cyklu, metotreksat $40 \mathrm{mg} / \mathrm{m}^{2}$ iv w 1. i 8. dniu oraz 5-fluorouracyl $600 \mathrm{mg} / \mathrm{m}^{2}$ iv w 1. i 8. dniu. Cykle powtarzano co 4 tygodnie.

Wyniki. Mediana średniej względnej intensywności dawki dla wszystkich leków wyniosła 86\%, w tym dla cyklofosfamidu, metotreksatu i 5-fluorouracylu odpowiednio 83\%, 77\% i 93\%. Pięcio- i dziesięcioletnie przeżycia całkowite wynosiły odpowiednio 76\% i 62\%, a przeżycia bez nawrotu choroby — 69\% i 59\%. W analizie wieloczynnikowej jedynymi znamiennymi czynnikami rokowniczymi były liczba zajętych przerzutami pachowych węzłów chłonnych oraz średnia względna intensywność dawki chemioterapii — wartość $\geq 78 \%$ związana była ze znamiennie dłuższym czasem przeżycia (współczynnik ryzyka 0,60; p <0,001) i czasem do nawrotu choroby (współczynnik ryzyka 0,57; p=0,045). Wnioski. Względna intensywność dawki chemioterapii z 78\% związana była z wydłużeniem czasu przeżycia i czasu do nawrotu choroby. Obniżenie wartości leukocytów, erytrocytów, hemoglobiny i płytek krwi nie miało prognostycznego znaczenia.
\end{abstract}

\section{Prognostic significance of dose intensity and haematological toxicity in breast cancer patients administered with adjuvant CMF chemotherapy}

Introduction. The aim of the study was to assess the prognostic significance of selected clinical factors, including dose intensity and haematological toxicity in breast cancer patients administered with adjuvant CMF chemotherapy. Material and methods. The study group were 264 patients who received 6 CMF cycles between 1990 and 1997. The CMF regimen consisted of cyclophosphamide $100 \mathrm{mg} / \mathrm{m}^{2}$ p.o. on days $1-14$, methotrexate $40 \mathrm{mg} / \mathrm{m}^{2}$ i.v. on days 1 and 8 , and 5 -fluorouracil $600 \mathrm{mg} / \mathrm{m}^{2}$ i.v. on days 1 and 8, every four weeks, for a total of six cycles.

Results. Median follow-up was 7.7 years (range 4.0-11.6 years). The dose intensity of administered cyclophosphamide, methotrexate and 5 -fluorouracil relative to the planned dose intensity was calculated for each patient. Median average relative dose intensity for all drugs was $86 \%$ ( $83 \%, 77 \%$ and $93 \%$ for cyclophosphamide, methotrexate and 5 -fluorouracil, respectively). Actuarial survival probability at 5 and 10 years was $76 \%$ and $62 \%$, and disease free survival probability $69 \%$ and $59 \%$. Using multivariate analysis the number of involved lymph nodes and relative dose intensity were the only significant prognostic factors. A value of $78 \%$ or more was associated with longer overall survival (hazard ratio $0.6 ; p=0.045$ ) and time to relapse (hazard ratio $0.57 ; p<0.001$ ).

${ }^{1}$ Klinika Onkologii i Radioterapii

Gdański Uniwersytet Medyczny

${ }^{2}$ Oddział Onkologii Klinicznej

Opolskie Centrum Onkologii 
Conclusion. Relative dose intensity of $78 \%$ or more was associated with longer overall survival and time to relapse. Decreased values of white blood cells, erythrocytes, haemoglobin and platelets did not carry prognostic information.

NOWOTWORY Journal of Oncology 2014; 64, 2: 135-142

Słowa kluczowe: rak piersi, chemioterapia pooperacyjna, intensywność dawki, toksyczność hematologiczna

Key words: breast cancer, adjuvant chemotherapy, dose intensity, haematoligical toxicity

\section{Wstęp}

Jednym z czynników potencjalnie wpływających na skuteczność pooperacyjnej chemioterapii u chorych na raka piersi jest jej intensywność, określana jako ilość leku podana w jednostce czasu [1-3]. Zarówno dane z badań retrospektywnych, jak i wyniki prospektywnych badań klinicznych wskazują, że należy unikać pochopnego zmniejszania dawek chemioterapii lub stosowania dawek niższych niż standardowe. Sugeruje się, że skuteczność chemioterapii zależy od jej intensywności oraz od indywidualnej wrażliwości chorego; od tych samych czynników zależy także toksyczność leczenia. Mielosupresja jest najczęściej występującym powikłaniem utrudniającym zrealizowanie zaplanowanej chemioterapii. Powoduje ona często odraczanie terminów kolejnych cykli leczenia lub zmniejszanie dawek leków. W niektórych nowotworach leukopenia towarzysząca chemioterapii może być paradoksalnie korzystnym czynnikiem rokowniczym [4-7]. Być może zależność ta wynika także $z$ tego, że nasilona leukopenia jest konsekwencją większej intensywności leczenia. Wysunięto jednak także hipotezę, że istnieje indywidualna zależność pomiędzy chemiowrażliwością układu krwiotwórczego i chemiowrażliwością komórek nowotworu, a powikłania hematologiczne mogą być wskaźnikiem skuteczności chemioterapii uzupełniającej zabieg operacyjny [7].

W niniejszym badaniu oceniano związek pomiędzy toksycznością hematologiczną i intensywnością dawki pooperacyjnej chemioterapii a odległymi wynikami leczenia u chorych na raka piersi.

Wszystkie chore operowane były przez jeden zespół chirurgów, a następnie kwalifikowane do dalszego leczenia przez zespół onkologów kierujących się jednolitymi wskazaniami. Po ukończeniu leczenia ten sam zespół prowadził wieloletnie badania kontrolne wszystkich chorych.

\section{Materiał i metody Material}

Niniejsza praca stanowi retrospektywną analizę wyników leczenia w grupie chorych na raka piersi, które otrzymały chemioterapię w uzupełnieniu zabiegu operacyjnego. Analizowaną grupę wyłoniono spośród 723 chorych na raka piersi, które pomiędzy 1 stycznia 1990 r. a 31 grudnia 1997 r. poddano radykalnej amputacji piersi sposobem Pateya. Dokumentacji lekarskiej nie odnaleziono w 29 przypadkach, z analizy wyłączono również 4 chore, u których rozpoznano chorobę Pageta oraz 6 chorych leczonych wcześniej z powodu raka przeciwległej piersi. Spośród pozostałych 684 chorych 293 otrzymały uzupełniającą chemioterapię. Z analizy wyłączono 28 chorych, u których leczenie było niepełne (1-5 cykli chemioterapii) oraz jedną chorą, która otrzymała leczenie $z$ udziałem antracyklin. Analizą objęto zatem 264 chore, które otrzymały pooperacyjną chemioterapię składającą się z 6 cykli wg schematu CMF.

Średnia wieku ogółu chorych wynosiła 46 lat. Ponieważ w dokumentacji źródłowej informacje dotyczące stanu menopauzalnego dostępne były dla zaledwie $60 \%$ chorych, za moment wystąpienia menopauzy przyjęto wiek 50 lat. Z powodu braku tych danych w analizie statystycznej nie uwzględniono stanu menopauzalnego, a wiek traktowano jako zmienną ciągłą. Charakterystykę badanej grupy przedstawiono w tabeli I.

Ocenę stopnia zaawansowania przeprowadzono przed rozpoczęciem leczenia na podstawie badania palpacyjnego, mammografii, zdjęcia rentgenowskiego klatki piersiowej oraz badań laboratoryjnych (morfologia z rozmazem, bilirubina całkowita, transaminazy, mocznik i kreatynina). Zaawansowanie nowotworu określano na podstawie klasyfikacji TNM z roku 1986. Określano także stopień zaawansowania, ustalony w wyniku badania histopatologicznego preparatu operacyjnego, który został także uwzględniony w niniejszej analizie.

\section{Metody}

Do pooperacyjnej chemioterapii kwalifikowano chore w stanie przedmenopauzalnym lub okołomenopauzalnym, u których stwierdzono co najmniej jedną z następujących cech: przerzuty do pachowych węzłów chłonnych, mała liczba węzłów chłonnych znalezionych w usuniętym materiale operacyjnym, drugi lub trzeci stopień zróżnicowania w skali Blooma-Richardsona oraz obecność zatorów w naczyniach krwionośnych i/lub limfatycznych. U 252 chorych (95,5\%) zastosowano chemioterapię CMF z udziałem cyklofosfamidu podawanego doustnie, u 7 (2,5\%) — z udziałem cyklofosfamidu podawanego dożylnie, a 5 (2\%) otrzymało w trakcie kuracji zarówno doustną, jak i dożylną postać cyklofosfamidu. Schemat CMF z udziałem doustnego cyklofosfamidu zakładał podawanie kolejnych cykli co 4 tygodnie, z przerwą w przyjmowaniu leków od dnia 15. do 28. Stosowano nastę- 
Tabela I. Charakterystyka kliniczna chorych

\begin{tabular}{|c|c|}
\hline Liczba chorych & 264 \\
\hline \multicolumn{2}{|l|}{ Wiek } \\
\hline średnia & 46 \\
\hline mediana & 46 \\
\hline zakres & $30-62$ \\
\hline \multicolumn{2}{|c|}{$\begin{array}{l}\text { Miejscowe zaawansowanie guza w badaniu } \\
\text { histopatologicznym } n=197\end{array}$} \\
\hline pT1 & $63(24 \%)$ \\
\hline pT2 & $126(47 \%)$ \\
\hline pT3 & $8(3 \%)$ \\
\hline pTX & $67(26 \%)$ \\
\hline \multicolumn{2}{|c|}{ Liczba węzłów chłonnych z przerzutami nowotworu $n=264$} \\
\hline 0 & 93 (35\%) \\
\hline $1-3$ & 98 (37\%) \\
\hline$>3$ & $73(28 \%)$ \\
\hline \multicolumn{2}{|c|}{ Postacie histologiczne $n=264$} \\
\hline rak przewodowy & 217 (82\%) \\
\hline rak zrazikowy & $42(16 \%)$ \\
\hline inne & $5(2 \%)$ \\
\hline \multicolumn{2}{|c|}{$\begin{array}{l}\text { Stopień zróżnicowania histologicznego } \\
\text { wg Blooma-Richardsona } n=191\end{array}$} \\
\hline G1 & $1(0,4 \%)$ \\
\hline G2 & 117 (44\%) \\
\hline G3 & $73(28 \%)$ \\
\hline nie oceniono & $73(28 \%)$ \\
\hline
\end{tabular}

pujące dawki leków: cyklofosfamid $100 \mathrm{mg} / \mathrm{m}^{2}$ doustnie od dnia 1. do 14., metotreksat $40 \mathrm{mg} / \mathrm{m}^{2} \mathrm{iv}$ w dniach 1. i 8 . oraz fluorouracyl $600 \mathrm{mg} / \mathrm{m}^{2}$ iv w dniach 1. i 8. Schemat CMF z udziałem dożylnego cyklofosfamidu powtarzano co 3 tygodnie, stosując leki w następujących dawkach: cyklofosfamid $500 \mathrm{mg} / \mathrm{m}^{2}$ iv dnia 1. i 8., metotreksat $40 \mathrm{mg} / \mathrm{m}^{2}$ iv dnia 1. i 8., fluorouracyl $600 \mathrm{mg} / \mathrm{m}^{2}$ iv dnia 1. i 8. Zmiana formy podawania leku z doustnej na dożylną spowodowana była we wszystkich przypadkach złą tolerancją doustnego preparatu. U 7 chorych zastosowanie wyłącznie dożylnego preparatu było spowodowane przejściowym brakiem dostępności leku w formie doustnej. U większości chorych leczenie przebiegało planowo, natomiast u 86 (33\%) wystąpiła konieczność wydłużenia przerw pomiędzy kolejnymi cyklami chemioterapii, spowodowana głównie toksycznością hematologiczną oraz zakażeniami.

\section{Ocena toksyczności hematologicznej}

Na 1-5 dni przed rozpoczęciem każdego cyklu chemioterapii u wszystkich chorych określono liczbę leukocytów, erytrocytów, płytek krwi oraz stężenie hemoglobiny. W przypadku obniżenia parametrów morfologii krwi, uniemożliwiających podanie kolejnego cyklu chemioterapii, po tygodniu powtarzano badanie morfologii krwi i leczenie wznawiano po normalizacji wartości hematologicznych. Ostatnią ocenę morfologii wykonywano w czwartym tygodniu szóstego cyklu chemioterapii. W analizowanej grupie chorych w trakcie leczenia nie stwierdzono ani jednego przypadku zagrażających życiu zakażeń związanych z obniżeniem liczby białych ciałek krwi lub krwawień związanych z małopłytkowością. Na podstawie dostępnych danych nie można było ocenić częstości występowania gorączki neutropenicznej, ponieważ informacja dotycząca liczby neutrocytów u znacznej części chorych była niedostępna. Dwie chore wymagały przetoczenia masy erytrocytarnej z powodu obniżenia stężenia hemoglobiny poniżej $8,0 \mathrm{~g} / \mathrm{dl}$.

\section{Intensywność dawki}

$\mathrm{U}$ wszystkich chorych dostępne były pełne dane na temat dawek leków podanych w ciągu całej kuracji. Aby ocenić intensywność stosowanego leczenia, dla każdej chorej obliczono intensywność dawki przy użyciu metody opisanej przez Hryniuka [8]. Całkowitą ilość każdego leku (osobno dla cyklofosfamidu, metotreksatu i 5-fluorouracylu) obliczono w miligramach, sumując dawki podane w poszczególnych cyklach. Za całkowity czas trwania leczenia przyjęto okres liczony od pierwszego dnia pierwszego cyklu chemioterapii do ostatniego dnia szóstego cyklu (dzień 28.). Dla każdej chorej obliczono względną intensywność dawki dla poszczególnych leków oraz średnią względną intensywność dawki.

Rzeczywistą intensywność dawki (RID) dla poszczególnych leków obliczono, posługując się wzorem:

$\mathrm{RID}=\frac{\text { całkowita dawka leku w miligramach }}{\text { powierzchnia ciała } \mathrm{w}^{2} \times \text { liczba tygodni leczenia }}$

W ten sam sposób obliczono należną intensywność dawki (NID), obejmującą wyliczone planowane dawki leków (tj. dawki, które by chora otrzymała, gdyby nie wystąpiły żadne powody do ich zmniejszenia). Wyrażoną w procentach względną intensywność dawki (WID) dla każdego leku obliczano z wzoru:

$$
\mathrm{WID}=\frac{\mathrm{RID}}{\mathrm{NID}}
$$

Średnią względną intensywność dawki $\left(\right.$ WID $\left._{\text {śr }}\right)$ dla wszystkich leków uzyskiwano, dodając względne intensywności dawki dla poszczególnych leków i dzieląc tę wartość przez liczbę stosowanych leków według wzoru:

$$
W I D_{s r}=\frac{W I D_{C T X}+W I D_{M T X}+W I D_{5-F U}}{3}
$$

gdzie WID ${ }_{\text {CTX }}$ Oznacza względną intensywność dawki cy-

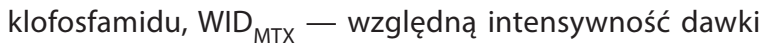
metotreksatu, a WID 5-Fu $_{-}$względną intensywność dawki 5-fluorouracylu. 


\section{Hormonoterapia}

Leczenie hormonalne $w$ uzupełnieniu chemioterapii otrzymało w badanej grupie 27 chorych (10\%). Hormonoterapia obejmowała codzienne podawanie tamoksyfenu w dawce $20 \mathrm{mg} /$ dobę przez 2 lata lub 5 lat (na podstawie wyników badań klinicznych ewentualnie wydłużono czas trwania standardowej hormonoterapii z 2 do 5 lat).

\section{Radioterapia}

Uzupełniającą radioterapię zastosowano u 43 chorych (16,3\%). Kwalifikowano do niej chore z co najmniej 4 przerzutami do pachowych węzłów chłonnych, z naciekiem przekraczającym torebkę węzłów chłonnych, dużym wymiarem guza pierwotnego lub naciekaniem mięśni lub skóry. Napromienianie rozpoczynano w ciągu 6 tygodni od zakończenia pooperacyjnej chemioterapii.

\section{Analiza statystyczna}

Czas przeżycia analizowano przy zastosowaniu metody Kaplana-Meyera. Czas ten określano od daty zabiegu operacyjnego do daty ostatniej obserwacji lub daty zgonu. Czas do nawrotu choroby stanowił okres od daty zabiegu operacyjnego do daty stwierdzenia nawrotu miejscowego, rozsiewu lub zgonu z innych przyczyn niż choroba nowotworowa. Analizę jednoczynnikową czasu przeżycia przeprowadzono przy użyciu testu log-rank. Współczynniki względnego ryzyka obliczono poprzez wprowadzenie poszczególnych zmiennych do jednoczynnikowego modelu Coxa. Aby ocenić precyzję określenia współczynników ryzyka, obliczono ich 95-procentowe przedziały ufności. Analizę wieloczynnikową przeprowadzono z zastosowaniem modelu regresji Coxa, ze wsteczną eliminacją zmiennych, których wpływ na czas przeżycia był nieznamienny w teście Walda. Warunek proporcjonalności ryzyka w czasie został zweryfikowany testem Schoenfelda. Rozkłady zmiennych kategoryzowanych w grupach porównano przy użyciu testu chi². Analizę korelacji przeprowadzono metodą nieparametryczną (korelacja Spearmana). Większość analizowanych zmiennych nie spełniała założeń rozkładu normalnego, co zweryfikowano testem Shapiro-Wilka. Do analizy statystycznej wykorzystano programy S-PLUS 2000 oraz Statistica 5.0.

\section{Wyniki}

Mediana czasu obserwacji wyniosła dla całej grupy chorych 7,7 roku (4-11,6). Udział trzyletnich przeżyć wynosił 86\% (95-procentowy przedział ufności 82-90\%), pięcioletnich $76 \%$ (71-82\%), a dziesięcioletnich 62\% (55-70\%). Nie osiągnięto mediany czasu przeżycia dla całej grupy chorych. W okresie obserwacji zmarły 84 chore (31\%), 79 z powodu progresji choroby nowotworowej, a 5 z innych przyczyn.

Średnia względna intensywność dawki analizowana była jako zmienna ciągła, kategoryzację przeprowadzono dopiero po skonstruowaniu ostatecznego modelu statystycznego.

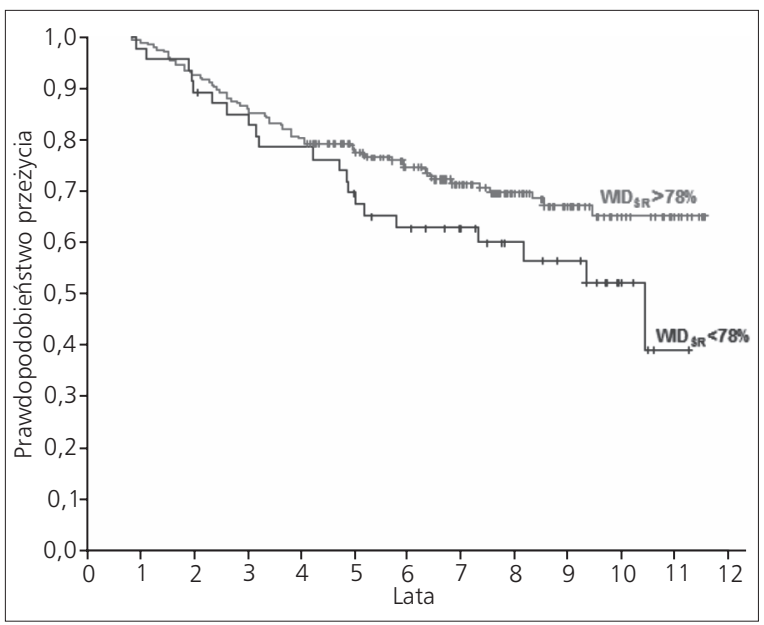

Rycina 1. Prawdopodobieństwo przeżycia całkowitego w zależności od średniej względnej intensywności dawki w grupie 264 chorych otrzymujących pooperacyjną chemioterapię $(p=0,045)$

Stwierdzono, że punkt odcięcia 78\% pozwala na najlepsze zobrazowanie wpływu średniej względnej intensywności dawki na czas przeżycia i czas do nawrotu choroby. Średnia względna intensywność dawki wyższa lub równa 78\% okazała się niezależnym korzystnym czynnikiem rokowniczym w analizie czasu przeżycia (współczynnik ryzyka 0,6; 95-procentowy przedział ufności 0,37-0,99; $p=0,045$ ) oraz $w$ analizie czasu do nawrotu choroby (współczynnik ryzyka 0,57; 95-procentowy przedział ufności 0,35-0,92; $\mathrm{p}<0,001$ ). W analizie jednoczynnikowej czasu całkowitego przeżycia istotny wpływ na ryzyko zgonu miały: wiek ( $p=0,024)$, liczba zajętych przerzutami pachowych węzłów chłonnych ( $p<0,001$ ), obecność naciekania przez nowotwór otaczających tkanek ( $p=0,0019)$, obecność zatorów w naczyniach krwionośnych i limfatycznych $(p<0,001)$ oraz liczba płytek krwi $(p=0,05)$.

W analizie wieloczynnikowej przy użyciu modelu Coxa wyłoniono dwa wzajemnie niezależne i znamienne czynniki rokownicze: liczbę zajętych przerzutami pachowych węzłów chłonnych $(p<0,001)$ oraz względną intensywność dawki $(p<0,001)$. Prawdopodobieństwo przeżycia 5 lat dla chorych bez zajęcia węzłów chłonnych wynosiło $90 \%$, z przerzutami do 1-3 węzłów - 83\%, a z przerzutami do > 3 węzłów - 51\%. Mediana czasu przeżycia całkowitego u chorych z wartością średniej względnej intensywności dawki < 78\% wynosiła 9,5 roku, natomiast dla średniej względnej intensywności dawki $\geq 78 \%$ mediana nie została osiągnięta (ryc. 1).

W badanej grupie 264 chorych odsetek trzyletnich przeżyć bez nawrotu nowotworu wyniósł 80\% (95-procentowy przedział ufności 76-85\%), pięcioletnich 69\% (95\% przedział ufności 63-74\%) i dziesięcioletnich 59\% (95-procentowy przedział ufności 52-67\%). Nie osiągnięto mediany czasu do nawrotu nowotworu. 


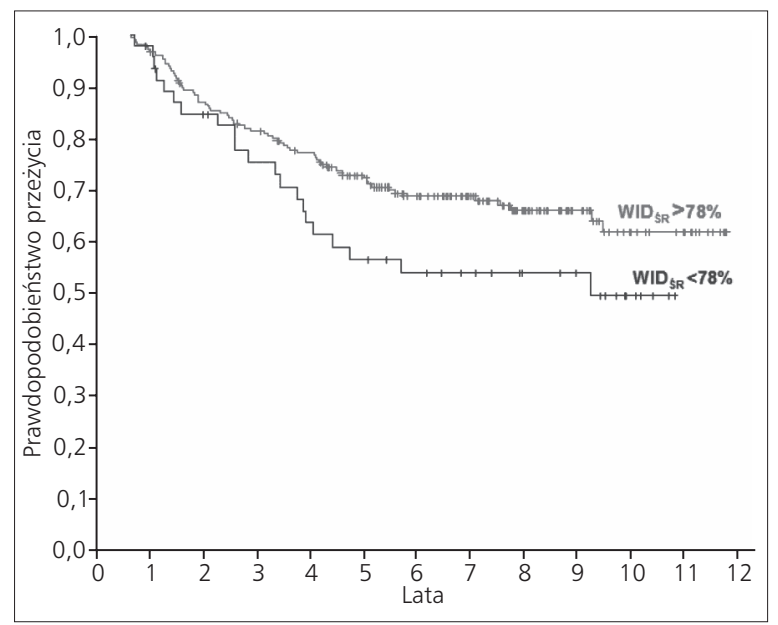

Rycina 2. Prawdopodobieństwo przeżycia bez nawrotu nowotworu w zależności od średniej względnej intensywności dawki w grupie 264 chorych otrzymujących pooperacyjną chemioterapię $(p<0,001)$

W analizie jednoczynnikowej czasu przeżycia bez nawrotu nowotworu wyodrębniono następujące czynniki rokownicze: liczba zajętych przerzutami pachowych węzłów chłonnych ( $p<0,001)$, obecność naciekania przez nowotwór otaczających tkanek ( $p=0,007)$, obecność zatorów w naczyniach krwionośnych i limfatycznych $(p=0,004)$ oraz względna intensywność dawki $(p=0,009)$. Najniższe stwierdzane wartości płytek krwi miały graniczną wartość rokowniczą ( $p=0,058)$. W analizie wieloczynnikowej z zastosowaniem modelu Coxa wyodrębniono dwa niezależne i znamienne czynniki rokownicze: liczbę zajętych przerzutami pachowych węzłów chłonnych oraz średnią względną intensywność dawki. Odsetki pięcioletnich przeżyć bez nawrotu nowotworu dla chorych bez zajęcia węzłów chłonnych wynosiły $88 \%$, z przerzutami do $1-3$ węzłów - 64\%, a z przerzutami do > 3 węzłów - 49\%. Mediana czasu do nawrotu nowotworu u chorych, z wartością średniej względnej intensywności dawki < 78\% wynosiła 8,6 roku, natomiast wśród chorych ze średnią względną intensywnością dawki $\geq 78 \%$ mediana nie została osiągnięta (ryc. 2).

W niniejszej analizie uwzględniono wyniki morfologii krwi wykonywane w czwartym tygodniu każdego cyklu chemioterapii (6 wyników u każdej chorej). Danych dotyczących liczby leukocytów brakowało w 1,9\% przypadków, erytrocytów w 2,7\%, hemoglobiny w 2,5\% oraz płytek krwi w 3,7\% przypadków. Aby przeanalizować wpływ wskaźników hematologicznych na czas przeżycia i czas do nawrotu choroby,

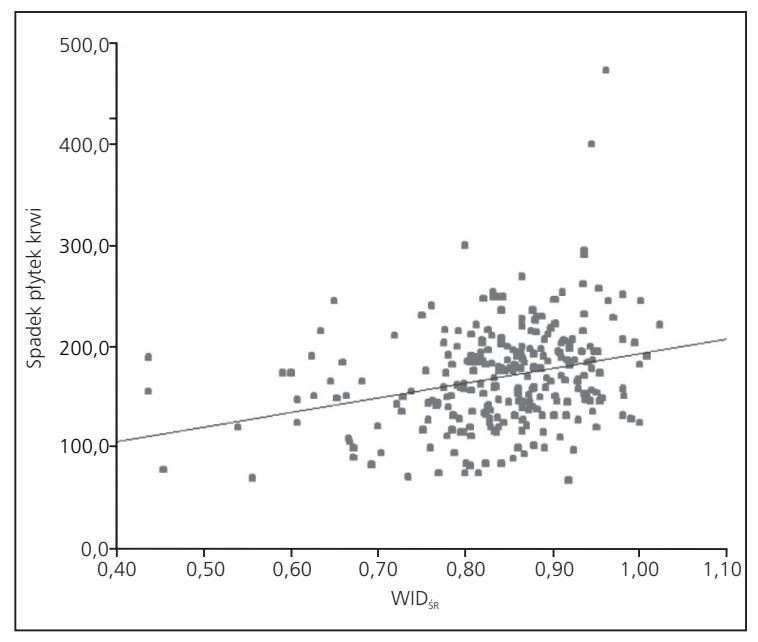

Rycina 3. Zależność pomiędzy najniższą liczbą płytek krwi w czasie pooperacyjnej chemioterapii a względną intensywnością dawki. Współczynnik korelacji $r=0,27 ; p<0,001$

wyodrębniono najniższą wartość omawianych wskaźników stwierdzoną u każdej chorej w ciągu całej 6-miesięcznej kuracji (do 28. dnia 6. cyklu chemioterapii). U żadnej chorej nie stwierdzono powikłań o 4. stopniu nasilenia (tab. 2). W analizie jednoczynnikowej jedynie najniższa wartość płytek krwi miała znamienny wpływ na czas przeżycia, przy czym wysokie wartości płytek krwi wiązały się z lepszym rokowaniem. Wskaźnik ten nie osiągnął jednak znamienności statystycznej w analizie wieloczynnikowej.

W analizie wielooczynnikowej czasu do nawrotu nowotworu żaden z analizowanych wskaźników morfologii krwi nie osiągnął znamienności statystycznej, przy czym spadek wartości płytek krwi osiągnął wartość graniczną $(p=0,058)$. Ponieważ liczba płytek krwi była jedynym parametrem morfologii krwi mającym znamienny wpływ na czas przeżycia w analizie jednoczynnikowej, przeprowadzono analizę zależności pomiędzy najniższymi wartościami płytek krwi a średnią względną intensywnością dawki (ryc. 3). Analiza ta wykazała silny związek pomiędzy tymi cechami: wyższe wartości płytek krwi umożliwiły podawanie pełnych dawek chemioterapii i planową realizację leczenia (wysoka WID $D_{\text {śr }}$ ), co z kolei w badanej grupie chorych związane było z dłuższym czasem przeżycia.

\section{Dyskusja}

Część chorych na raka piersi nie otrzymuje zaplanowanej dawki chemioterapii, przy czym skala tego zjawiska

Tabela II. Liczba i odsetek chorych, u których wystąpiła toksyczność hematologiczna (ocena wg Common Toxicity Criteria 2.0)

\begin{tabular}{|c|c|c|c|c|}
\hline Toksyczność & Liczba chorych (\%) & Stopień 1. & Stopień 2. & Stopień 3. \\
\hline Leukopenia & $83(31 \%)$ & $120(46 \%)$ & $53(20 \%)$ & $8(3 \%)$ \\
\hline Niedokrwistość & $149(56 \%)$ & $107(41 \%)$ & $7(3 \%)$ & $1(0,4 \%)$ \\
\hline Trombocytopenia & $246(93 \%)$ & $15(6 \%)$ & $3(1 \%)$ & - \\
\hline
\end{tabular}


jest w dużym stopniu zależna od schematu i intensywności leczania. W przeprowadzonym w Stanach Zjednoczonych retrospektywnym badaniu populacyjnym uzupełniającej chemioterapii, obejmującym 20.799 chorych na raka piersi leczonych w latach 1997-2000 stwierdzono, że u prawie 2/3 chorych średnia względna intensywność dawki nie przekraczała 85\% [9]. Zjawisko to dotyczyło 70-90\% chorych leczonych z zastosowaniem schematu CMF i 80-95\% chorych otrzymujących schematy zawierające antracykliny.

W niniejszej pracy niemal wszystkie chore otrzymywały schemat CMF z udziałem doustnego cyklofosfamidu, który w analizowanym okresie był najczęściej stosowany w pooperacyjnej chemioterapii chorych na raka piersi. Obecnie najczęściej stosowane są schematy zawierające antracykliny i taksoidy, których wyższą skuteczność udowodniono zwłaszcza wśród chorych z przerzutami do pachowych węzłów chłonnych [10-13]. Schemat CMF jest jednak nadal stosowany, na przykład u części chorych powyżej 65. roku życia [14] oraz w podtypach luminalnych raka piersi, gdzie jego skuteczność jest podobna do skuteczności schematów opartych na antracyklinach [15]. Znaczenie schematu CMF lub jego pochodnych może ponownie wzrosnąć w związku z wykazaniem zwiększonej wrażliwości na leki alkilujące w podgrupie chorych na raka piersi bez ekspresji receptorów steroidowych i HER2 (tzw. rak potrójnie ujemny) [16].

W niniejszym badaniu średnia względna intensywność dawki chemioterapii okazała się niezależnym czynnikiem rokowniczym zarówno w odniesieniu do czasu przeżycia, jak i czasu do nawrotu choroby. Zależność pomiędzy dawką leków cytotoksycznych a skutecznością leczenia chorych na raka piersi opisali po raz pierwszy Bonadonna i Valagussa [17]. Przeanalizowali oni dane pochodzące z dwóch badań klinicznych, z których w pierwszym porównywano leczenie operacyjne $z$ udziałem lub bez udziału pooperacyjnej chemioterapii CMF, a w drugim — ten sam schemat był podawany przez 6 lub 12 miesięcy. Za optymalną dawkę przyjęli oni całkowitą zaplanowaną dawkę leków, a następnie obliczyli rzeczywiste, całkowite podane dawki i wyrazili je w postaci odsetka dawki optymalnej. Analizie poddano średnią arytmetyczną dla poszczególnych leków. Założono, że zmniejszenie dawek każdego z trzech leków wchodzących w skład schematu ma taki sam wpływ na wyniki leczenia. Wyróżniono trzy grupy chorych w zależności od odsetka podanej dawki optymalnej: co najmniej $85 \%$ zaplanowanej dawki, 65-84\% i poniżej 65\%. Czas przeżycia bez nawrotu nowotworu w grupie chorych, które otrzymały najwyższe dawki, był znamiennie dłuższy w porównaniu z grupą, która otrzymała najniższą dawkę. Udział pięcioletnich przeżyć całkowitych w obu wymienianych grupach wynosił odpowiednio $67 \%$ i $48 \%$, a różnice we wskaźnikach przeżycia związane z intensywnością chemioterapii utrzymywały się po dwudziestu latach obserwacji [18]. Podobne wyniki uzyskano w innym badaniu, obejmującym 1350 chorych
[19]. W opinii autorów tego doniesienia znamiennie gorsze wyniki leczenia wśród chorych, które otrzymały poniżej $65 \%$ zaplanowanej dawki, spowodowane były tym, że zależność dawka-efekt nie ma charakteru liniowego, a raczej istnieje pewien poziom dawki (dose treshold), poniżej którego nie uzyskuje się istotnego efektu leczniczego. W innych pracach przyjmowano inne przedziały dawek, tak aby jak najlepiej wykazać ewentualną zależność. Tylko w niektórych pracach potwierdzono istnienie zależności pomiędzy podaną dawką wyrażoną jako odsetek planowanej dawki a czasem do nawrotu nowotworu i całkowitym czasem przeżycia [20, 21]. Również w niniejszym materiale, po przeanalizowaniu średniej względnej intensywności dawki jako zmiennej ciągłej i opracowaniu ostatecznego modelu statystycznego, wybrano poziom średniej względnej intensywności dawki (78\%) jako najlepiej dzielący badane chore na dwie grupy o znamiennie różnym rokowaniu.

W zbiorczej analizie intensywności dawki pooperacyjnej chemioterapii w 32 badaniach klinicznych z udziałem chorych na raka piersi w II stopniu zaawansowania, otrzymujących pooperacyjną chemioterapię, oceniono planowaną, a nie rzeczywistą intensywność chemioterapii w poszczególnych badaniach, przyjmując jako punkt odniesienia klasyczny schemat CMF z udziałem doustnego cyklofosfamidu [22]. W analizie tej nie oceniano rzeczywistej intensywności dawki, ponieważ dane te były niedostępne. Stwierdzono znamienną zależność pomiędzy założoną intensywnością dawki a czasem przeżycia bez nawrotu choroby. Zależność ta występowała u chorych zarówno przed 50., jak i po 50. roku życia, z zajęciem przerzutami 1-3, jak i większej liczby węzłów chłonnych. Wielu autorów podkreślało także, że metoda opracowana w tym badaniu nie uwzględnia synergizmu leków [20, 23], a powtórna analiza, obejmująca wyłącznie badania, w których stosowano schematy oparte o CMF, jak również inne badania nie potwierdziły tych wyników [20, 24]. Wpływu intensywności pooperacyjnej chemioterapii wg schematu CMF na czas przeżycia i czas do nawrotu nowotworu nie wykazano również w retrospektywnej analizie przeprowadzonej w Centrum Onkologii w Warszawie [25].

W niniejszym badaniu średnie względne intensywności dawki dla poszczególnych chorych obliczono na podstawie szczegółowych danych zawartych w dokumentacji źródłowej, czyli były to wartości rzeczywiste. Dodatkowo do obliczeń intensywności dawki posłużono się rzeczywistą liczbą cykli chemioterapii zastosowanych u poszczególnych chorych. W innych opracowaniach chore, które wcześniej zakończyły leczenie z powodu progresji choroby (w związku z czym podane im łączne dawki leków były z konieczności niższe), zaliczano do grupy o niskiej intensywności dawki. W efekcie wyniki w tej grupie były sztucznie zaniżone [26]. Weryfikację wniosków płynących z retrospektywnych badań przeprowadzono w dużych prospektywnych badaniach $\mathrm{z}$ randomizacją. W badaniu prowadzonym przez Cancer 
and Leukemia Group B 1550 chorych na raka piersi zakwalifikowanych do pooperacyjnej chemioterapii przydzielono losowo do trzech grup, w których stosowano schemat FAC (5-fluorouracyl, doksorubicyna, cyklofosfamid) o niskiej (300/30/300 mg/m² 4 cykle, co 4 tygodnie), średniej (400/40/400 mg/m² 6 cykli, co 4 tygodnie) lub wysokiej (600/60/600 mg/m² 4 cykle, co 4 tygodnie) intensywności dawki (ta ostatnia obejmowała dawki konwencjonalne). W grupie drugiej całkowita rzeczywista dawka leków była podobna jak w trzeciej, mimo że intensywność dawki była o 1/3 mniejsza. Po okresie obserwacji o medianie 9 lat udział pięcioletnich przeżyć był znamiennie wyższy w grupach z pośrednimi i wysokimi dawkami leków (odpowiednio 79\% i 77\%) w porównaniu z grupą leczoną niskimi dawka$\mathrm{mi}-72 \%(\mathrm{p}=0,0034)$. Stosowane $w$ tym badaniu wysokie i średnie dawki są obecnie uznawane za standardowe, przy czym przedstawione wyniki sugerują jedynie mniejszą skuteczność chemioterapii poniżej pewnego poziomu dawki [27]. Intensywność dawki cyklofosfamidu w połączeniu z doksorubicyną oceniano w badaniach B-22 i B-25 prowadzonych przez National Surgical Adjuvant Breast and Bowel Project (NSABP). Pomimo podawania dawek cyklofosfamidu 2 i 4 razy wyższych od standardowych i wspomagania chemioterapii czynnikiem pobudzającym kolonizację komórek szpiku nie uzyskano poprawy wyników leczenia w porównaniu ze standardową dawką 600 mg/m² [28, 29]. Nieskuteczność intensyfikacji chemioterapii, w tym stosowania bardzo wysokich dawek z przeszczepieniem autologicznego szpiku lub macierzystych komórek krwi obwodowej, potwierdziły również inne badania [30, 31]. Z kolei w badaniach z udziałem chorych na raka piersi z przerzutami do pachowych węzłów chłonnych skrócenie cykli chemioterapii zawierającej paklitaksel, cyklofosfamid i antracykliny wiązało się z poprawą wyników [32, 33].

W niniejszym materiale najniższe wartości parametrów morfologii krwi obserwowane w czasie chemioterapii nie miały niezależnego wpływu na czas przeżycia i czas do nawrotu nowotworu. Jedynym wskaźnikiem morfologii krwi, który wpływał na czas przeżycia w analizie jednoczynnikowej, była liczba płytek krwi - wyższe wartości związane były z lepszym rokowaniem. Wykazano równocześnie, że wysokie wartości płytek krwi były związane z wysoką intensywnością dawki, która w badanej grupie była korzystnym czynnikiem rokowniczym.

Zależność pomiędzy nasileniem leukopenii a rokowaniem wykazano w kilku badaniach retrospektywnych dotyczących chorych na raka piersi. W badaniu Saarto i wsp. [7] chore otrzymujące pooperacyjną chemioterapię zawierającą antracykliny, u których doszło do leukopenii III i IV stopnia, miały w analizie jednoczynnikowej znamiennie dłuższy czas przeżycia i czas do nawrotu choroby (odpowiednio $p=0,04$ i $p=0,01$ ). Podobne wyniki uzyskano $w$ innej retrospektywnej analizie przeprowadzonej przez ten sam zespół u chorych otrzymujących pooperacyjną chemioterapię z zastosowaniem schematu CMF, przy czym rokownicze znaczenie leukopenii nie potwierdziło się w analizie wieloczynnikowej [34].

W prospektywnym badaniu, w którym dawki chemioterapii indywidualnie modyfikowano tak, aby w przebiegu leczenia osiągnąć z góry założony stopień nasilenia leukopenii, nie uzyskano poprawy wyników leczenia, ale koncepcja ta jest nadal przedmiotem badań u chorych na raka piersi z przerzutami do pachowych węzłów chłonnych [35, 36]. Wpływu leukopenii i trombocytopenii na rokowanie nie stwierdzono również w badaniu III fazy porównującym skuteczność chemioterapii FAC o małej, średniej i wysokiej intensywności dawki [27].

W niniejszym badaniu możliwa była wyłącznie ocena morfologii krwi przeprowadzana bezpośrednio przed planowanym podaniem kolejnych cykli (26.-28. dzień), zatem nie można było ocenić rzeczywiście najniższych wartości wskaźników hematologicznych i ocenić ich wpływu na rokowanie. W badaniu Poikonena i wsp. [34] nie podano, w jakich dniach cyklu chemioterapii wykonywano badanie morfologii krwi, aczkolwiek autorzy zaznaczyli, że zależność pomiędzy najniższymi wartościami leukocytozy a rokowaniem była silniejsza, jeśli uwzględniono wyłącznie do badania wykonywane pomiędzy 9. a 14. dniem cyklu chemioterapii. Saarto i wsp. [7] wykorzystali w swojej analizie badania krwi wykonywane dzień przed planowanym kolejnym cyklem oraz około 10. dnia każdego cyklu. W prospektywnym badaniu Cancer and Leukemia Group B nie wykazano zależności pomiędzy wartościami parametrów morfologii krwi a rokowaniem [27].

Podsumowując, intensywność pooperacyjnej chemioterapii u chorych na raka piersi jest silnym i niezależnym czynnikiem wpływającym na jej skuteczność. Z kolei występowanie i nasilenie powikłań hematologicznych chemioterapii nie wykazują istotnego związku z rokowaniem.

Konflikt interesu: nie zgłoszono

\section{Dr n. med. Ewa Szutowicz}

Klinika Onkologii i Radioterapii Gdański Uniwersytet Medyczny ul. Dębinki 7, 80-211 Gdańsk

e-mail:eszut@gumed.edu.pl

Otrzymano: 18 września 2013 r.

Przyjęto do druku: 29 października 2013 r.

\section{Piśmiennictwo}

1. Green JA, Dawson AA, Fell LF, Murray S. Measurement of drug dosage intensity in MVPP therapy in Hodgkin's disease. Br J Clin Pharmacol 1980; 9: 511-514.

2. Hryniuk W, Bush $\mathrm{H}$. The importance of dose intensity in chemotherapy of metastatic breast cancer. J Clin Oncol 1984; 2: 1281-1288.

3. Wildiers $\mathrm{H}$, Reiser M. Relative dose intensity of chemotherapy and its impact on outcomes in patients with early breast cancer or aggressive lymphoma. Crit Rev Oncol Hematol 2011; 77: 221-240.

4. Yosef H, Slater A, Keen CW i wsp. Prednimustine (Sterecyt) versus cyclophosphamide both in combination with methotrexate and 5 -fluorouracil in the treatment of advanced breast cancer. Eur J Cancer 1993; 29A: 1100-1105. 
5. Jereczek-Fossa B, Jassem J, Karnicka-Mlodkowska i wsp. Does chemotherapy-induced leukopenia predict a response in small-cell lung cancer? J Cancer Res Clin Oncol 1998; 124: 106-112.

6. Nilsson B. Treatment intensity and quality of life in cancer chemotherapy. Res Clin Forums 1992; 14: 105-118.

7. Saarto T, Blomqvist C, Rissanen P i wsp. Haematological toxicity: a marker of adjuvant chemotherapy efficacy in stage II and III breast cancer. Br J Cancer 1997; 75: 301-305.

8. Hryniuk WM. The importance of dose intensity in outcome of chemotherapy. W: Hellman S, De Vita V, Rosenberg S (red.): Important Advances in Oncology, Philadelphia, PA: Lippincott; 1988, s. 121-141.

9. Lyman GH, Dale DC, Crawford J. Incidence and predictors of low dose-intensity in adjuvant breast cancer chemotherapy: a nationwide study of community practices. J Clin Oncol 2003; 21: 4524-4531.

10. Polychemotherapy for early breast cancer: an overview of the randomised trials. Early Breast Cancer Trialists' Collaborative Group. Lancet 1998; 352: 930-942.

11. Early Breast Cancer Trialists' Collaborative Group (EBCTCG). Comparisons between different polychemotherapy regimens for early breast cancer: meta-analyses of long-term outcome among 100000 women in 123 randomised trias. Lancet 2012; 379: 432-444.

12. Gennari A, Sormani MP, Pronzato P i wsp. HER2 status and efficacy of adjuvant anthracyclines in early breast cancer: a pooled analysis of randomized trials. J Nat I Cancer Inst 2008; 100: 14-20.

13. De Laurentiis M, Cancello G, D'Agostino D i wsp. Taxane-based combinations as adjuvant chemotherapy of early breast cancer: a meta-analysis of randomized trials. J Clin Oncol 2008; 26: 44-53.

14. Oladipo O, Coyle V, McAleer J i wsp. Achieving optimal dose intensity with adjuvant chemotherapy in elderly breast cancer patients: a 10-year retrospective study in a UK institution. Breast J 2012; 18: 16-22.

15. Cheang MC, Voduc KD, Tu D i wsp. Responsiveness of intrinsic subtypes to adjuvant anthracycline substitution in the NCIC.CTG MA.5 randomized trial. Clin Cancer Res 2012; 18: 2402-2412.

16. Munzone E, Curigliano G, Burstein $\mathrm{HJ}$ i wsp. CMF revisited in the 21st century. Ann Oncol 2012; 23: 305-311.

17. Bonadonna G, Valagussa P. Dose-response effect of adjuvant chemotherapy in breast cancer. N Engl J Med 1981; 304: 10-15.

18. Bonadonna G, Valagussa P, Moliterni A i wsp. Adjuvant cyclophosphamide, methotrexate and fluorouracil in node-positive breast cancer: the results of 20 years of folollow-up. N Engl J Med 1995; 332: 901-906.

19. Colleoni M, Price K, Castiglione-Gertsch M i wsp. Dose-response effect of adjuvant cyclophosphamide, methotrexate, 5-fluorouracil (CMF) in node-positive breast cancer. International Breast Cancer Study Group. Eur J Cancer 1998; 34: 1693-1700.

20. Henderson IC, Hayes DF, Gelman R. Dose-response in the treatment of breast cancer: a critical review. J Clin Oncol 1988; 6:1501-1515.

21. Geller NL, Hakes TB, Petroni GRi wsp. Association of disease-free survival and percent of ideal dose in adjuvant breast chemotherapy. Cancer 1990; 66: 1678-1684.

22. Hryniuk W, Levine MN. Analysis of dose intensity for adjuvant chemotherapy trials in stage II breast cancer. J Clin Oncol 1986; 4: 1162-1170.

23. Dodwell DJ, Gurney H, Thatcher N. Dose intensity in cancer chemotherapy. Br J Cancer 1990; 61: 789-794.

24. Ang PT, Buzdar AU, Smith TL i wsp. Analysis of dose intensity in doxorubicin-containing adjuvant chemotherapy in stage II and III breast carcinoma. J Clin Oncol 1989; 7: 1677-1684.
25. Głogowska I, Pieńkowski T, Lemańska l i wsp. Dose intensity of adjuvant CMF chemotherapy program for breast cancer. Nowotwory J Oncol 2001; 51: 27-33.

26. Redmond C, Fisher B, Wieand HS. The methodologic dilemma in retrospectively correlating the amount of chemotherapy received in adjuvant therapy protocols with disease-free survival. Cancer Treat Rep 1983; 67: 519-526.

27. Budman DR, Berry DA, Cirrincione CT i wsp. Dose and dose intensity as determinants of outcome in the adjuvant treatment of breast cancer. The Cancer and Leukemia Group B. J Natl Cancer Inst 1998; 90: 1205-1211.

28. Fisher B, Anderson S, Wickerham DL i wsp. Increased intensification and total dose of cyclophosphamide in a doxorubicin-cyclophosphamide regimen for the treatment of primary breast cancer: findings from National Surgical Adjuvant Breast and Bowel Project B-22. J Clin Oncol 1997; 15: 1858-1869.

29. Fisher B, Anderson S, DeCillis A i wsp. Further evaluation of intensified and increased total dose of cyclophosphamide for the treatment of primary breast cancer: findings from National Surgical Adjuvant Breast and Bowel Project B-25. J Clin Oncol 1999; 17: 3374-3388.

30. Fumoleau P, Chauvin F, Namer M i wsp. Intensification of adjuvant chemotherapy: 5-year results of a randomized trial comparing conventional doxorubicin and cyclophosphamide with high-dose mitoxantrone and cyclophosphamide with filgrastim in operable breast cancer with 10 or more involved axillary nodes. J Clin Oncol 2001; 19: 612-620.

31. Peters WP, Rosner GL, Vredenburgh JJ i wsp. Prospective, randomized comparison of high-dose chemotherapy with stem-cell support versus intermediate-dose chemotherapy after surgery and adjuvant chemotherapy in women with high-risk primary breast cancer: a report of CALGB 9082, SWOG 9114, and NCIC MA-13. J Clin Oncol 2005; 23: 2191-2200.

32. Citron ML, Berry DA, Cirrincione Ci wsp. Randomized trial of dose-dense versus conventionally scheduled and sequential versus concurrent combination chemotherapy as postoperative adjuvant treatment of node-positive primary breast cancer: first report of Intergroup Trial C9741/Cancer and Leukemia Group B Trial 9741. J Clin Oncol 2003; 21: 1431-1439.

33. Moebus V, Jackisch $\mathrm{C}$, Lueck HJ, i wsp. Intense dose-dense sequential chemotherapy with epirubicin, paclitaxel, and cyclophosphamide compared with conventionally scheduled chemotherapy in high-risk primary breast cancer: mature results of an AGO phase III study. J Clin Oncol 2010; 28: 2874-2880.

34. Poikonen P, Saarto T, Lundin J i wsp. Leucocyte nadir as a marker for chemotherapy efficacy in node-positive breast cancer treated with adjuvant CMF. Br J Cancer 1999; 80: 1763-1766.

35. Bergh J, Wiklund T, Erikstein B i wsp. Dosage of adjuvant G-CSF (filgrastim)-supported FEC polychemotherapy based on equivalent haematological toxicity in high-risk breast cancer patients. Scandinavian Breast Group, Study SBG 9401. Ann Oncol 1998; 9: 403-411.

36. Margolin S, Bengttson NO, Carlsson L i wsp. A randomised feasibility/phase II study (SBG 2004-1) with dose-dense/tailored epirubicin, cyclophoshamide (EC) followed by docetaxel $(T)$ or fixed dosed dose-dense $\mathrm{EC} / \mathrm{T}$ versus $\mathrm{T}$, doxorubicin and $\mathrm{C}$ (TAC) in node-positive breast cancer. Acta Oncologica 2011; 50: 35-41. 